\title{
Canada's doctors vote to discontinue financial support for CMAJ
}

Published at www.cmaj.ca on Aug. 26

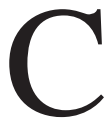

anada's doctors have directed the Canadian Medical Association to craft a business plan for CMAJ in which physicians won't have to pay a dime out of their own pockets to offset the decline in journal advertising revenues which ensued as a result of the economic downturn.

Delegates to the CMA's 143rd annual meeting in Niagara Falls, Ontario, passed a motion Wednesday that compels the association to discontinue direct financial support for $C M A J$, commencing in 2012.

Although CMAJ garnered roughly $\$ 13$ million in profits for CMA over the course of two decades leading up to 2008 , it has required a combined $\$ 4.5$ million contribution from the association over the past three fiscal years to allay the effects of declining advertising revenues now being felt throughout the scientific publishing industry.

The motion would leave $C M A J$ with a shortfall of $\$ 2$ million on its roughly \$7-million budget and facing some hard choices, says Dr. Brad Fritz, chair of the CMA's ad hoc working group on publications.

"I don't think it's feasible at this point, barring some major changes, either in the world of publishing, bringing more revenues to us, or a substantial reduction in the amount of money $C M A J$ spends, to produce their publications, both the paper and the electronic versions."

Fritz adds that there appears to be a major discontinuity between delegates who supported the motion and CMA's 73000 members, some $70 \%-80 \%$ of whom have consistently indicated in internal association polling that they strongly support CMAJ. "Every time we ask, they say that they want us to keep doing this and, in fact, to make it better."

Fritz was also befuddled that delegates would be averse to spending

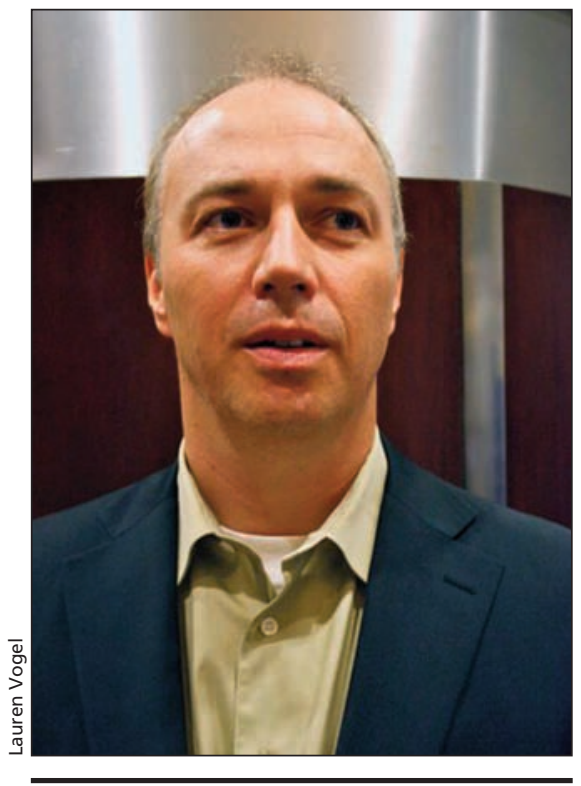

Dr. Shawn Whatley of Mount Albert, Ontario, sponsored a motion at the CMA's 143rd annual meeting to discontinue direct financial support for CMAJ, commencing in 2012.

roughly $\$ 12$ per year on $C M A J$, given that members of other medical associations are willing to spend far more to maintain a journal. "I know that the anesthesia journal and the ophthalmology journal, their members say they are paying about $\$ 60$ per year," he says, adding that the "\$12 is considerably less than what a lot of other member organizations expect as a contribution per member."

"It's difficult to know where all of this leaves us," Fritz says, expressing hope that once the new business plan is developed and presented to the 2011 annual general meeting, CMA delegates will reconsider their position and squarely address whether they want to discontinue financial support for the journal as it celebrates its 100th year of operations.

"Is the value to the members such that, regardless of the cost, we should be producing what many people inside and outside the organization, including members, think is a world-class medical journal?"

The motion, which called for CMA's board of directors to "present to General Council in 2011, for implementation in 2012, a sustainable business plan for the CMAJ that does not utilize membership fees," was passed with a nary a voice of dissent. In fact, not a single delegate rose to address the motion or defend the value of the journal. The motion passed by a 150 $(80 \%)$ to $33(18 \%)$ margin, with four abstentions (2\%).

Motion sponsor Dr. Shawn Whatley of Mount Albert, Ontario, says doctors faced a simple choice. "We either go for cost neutrality or we continue to fund a non-profitable journal."

Whatley also indicated his aim was to demonstrate to the government that doctors can be fiscally responsible. "I think this is an opportunity to show government that we can handle successfully economic challenges. I think we have no credibility if we tell the government to be efficient, cut costs and deliver a good product and yet we can't do the same with our own journal."

"Sustainability and accountability are the cornerstones in the health care transformation agenda, and isn't that something we also want for the CMAJ?" Whatley asked, adding that "we need to show that money is being well spent. We have to demonstrate there's value for money."

"The CMAJ will have to determine whether or not what they're producing is value for money," Whatley says. "Is this really what CMA members want? I think a simple way to find out might be to ask the membership whether or not they would voluntarily contribute a subscription. Perhaps they would rather not do that."

Whatley also noted that "one of the issues that has to be addressed is the fact that, because of tight economic 
times, advertisers aren't spending as much money."

But CMAJ's advertising challenges go beyond the economy. For example, the journal is currently precluded from seeking advertising from the lucrative banking or financial industries on the grounds that such ads would conflict with the interests of the investment arm of Canada's doctors, MD Management Limited.

Ironically, while delegates passed the motion to discontinue support for $C M A J$, they passed another demand- ing that CMAJ "reverse" last January's decision to discontinue translation of abstracts and editorials into the French language. The cost-cutting measure was implemented after data indicated that no one was reading the French versions of abstracts and editorials.

But several delegates bridled at the affront to bilingualism. "Money problems shouldn't be a consideration when fundamental values are at stake," said Montréal, Quebec, delegate Dr. Stephen Rosenthal.
Others saw no conflict between yanking support for CMAJ and demanding that it spend monies on specific activities. "We passed a motion regarding the finances of the journal but the publishing committee will work on that," said Ottawa, Ontario, delegate Dr. Atul Kapur. "This is an important enough priority that we [must] tell the journal 'make it so'." - Wayne Kondro and Lauren Vogel, CMAJ

DOI:10.1503/cmaj.109-3356 